\title{
A DEFENCE OF STATUTORY PROPERTY
}

\section{David AC Bullock*}

In "Statutory Property: Is it a Thing?" (2016) 47 VUWLR 411, Ben France-Hudson argues that tradable environmental allowances, like emissions units and fishing quota, are not "statutory property" and should instead simply be described and understood as "private property". In doing so, France-Hudson draws on a theory of private property as embodying norms of social obligation. This article defends the view of tradable environmental allowances as statutory property - though that term has a number of definitions - and argues that property in tradable environmental allowances can be explained by an orthodox understanding of the law of property.

\section{INTRODUCTION}

In his article "Statutory Property: Is it a Thing?", Ben France-Hudson argues that "statutory property" should be rejected and instead considered "private property". ${ }^{1}$ The argument is situated around what I will refer to as "tradeable environmental allowance" regimes, such as the New Zealand Emissions Trading Scheme (ETS) and the fisheries Quota Management System (QMS). ${ }^{2}$ These regimes regulate the use of open access resources by creating individual access entitlements in the form of tradeable environmental allowances (such as emissions units or individual transferable quota). ${ }^{3}$ In support of categorising these allowances simply as "private property", France-Hudson deploys a "social obligations" theory of property rights, which treats private property as a flexible,

* BCA, LLB (Hons), Victoria University of Wellington, LLM, Yale University.

1 Ben France-Hudson "Statutory Property: Is it a Thing?" (2016) 47 VUWLR 411 at 412.

2 I use Carol Rose's phrase "tradable environmental allowances" in this article to refer to the variety of environmental policies that rely on tradable property and property-like rights to regulate access to environmental resources, with a note to the many other names used to describe the same concept. Carol M Rose "Common Property, Regulatory Property, and Environmental Protection: Comparing CommunityBased Management to Tradable Environmental Allowances" in National Research Council (ed) The Drama of the Commons (National Research Council, 2002) 233 at 234.

3 Terry L Anderson and Gary D Libecap Environmental Markets: A Property Rights Approach (Cambridge University Press, Cambridge, 2014). 
pluralistic social institution that imposes norms of social obligation on property owners in the pursuit of meeting human needs. ${ }^{4}$

This article responds to the approach taken by France-Hudson. I do not disagree with FranceHudson's ultimate conclusion - that tradable environmental allowances are properly viewed as the property of allowance holders - though I do take issue with the framing of the dichotomy created between statutory and private property. France-Hudson offers a narrow definition of statutory property as property "solely governed by the rules contained in the statute". ${ }^{5}$ This definition appears to be linked to Grinlinton's similar description of the unusual status of resource consents under the Resource Management Act 1991: consents are deemed to be neither real nor personal property. ${ }^{6}$ It does not appear that Grinlinton intended the term, as he used it, to apply to tradable environmental allowances generally. As will be seen, notions of property derived from statute frequently used in the literature on tradeable environmental allowances embrace wider property concepts.

I argue that there is value in referring to tradable environmental allowances as statutory property. Property rights created by statute are defined according to the terms of their constituting statute. I do not agree with France-Hudson that this means the ordinary private law of property does not apply to property born of statute (unless, of course, the statute explicitly excludes that law, as the Resource Management Act 1991 appears to do). What it does mean is that the nature, content and bounds of that property may be modified by statute in a manner that affects its interaction with the ordinary law of property (a statute may, for example, limit the transferability, duration or exclusivity of the property it creates). It is helpful - theoretically and practically - to refer to property created by statute as "statutory property" as the description signals that one must look to the statute to determine the nature of the property and its relationship with the common law.

Finally, I argue that there is no need to resort to a social obligations theory of property to explain the nature of property in tradable environmental allowances. Indeed, used as it is by France-Hudson, a social obligation understanding of property law ends up looking a lot like the concept of statutory property I have just described. This is not a criticism of efforts to give greater recognition to the social foundations of the institution of property, but in the case at hand social obligations theory provides more heat than light.

4 France-Hudson, above $\mathrm{n} \mathrm{1,} \mathrm{at} 412$. The literature on the social obligations theory of property is discussed in Part V.

5 At 423

6 David Grinlinton "Evolution, Adaption, and Invention: Property Rights in Natural Resources in a Changing World" in David Grinlinton and Prue Taylor (eds) Property Rights and Sustainability: The Evolution of Property Rights to Meet Ecological Challenges (Martinus Nijhoff Publishers, Leiden, 2011) 275 at 296, referring to s 122(1) of the Resource Management Act 1991, which provides: "A resource consent is neither real nor personal property." 
The article begins in Part II by providing some definitional clarity to the concept of statutory property. Part III considers the two property questions that arise in the context of tradable environmental allowance regimes. Having established what statutory property is, and where it fits, Part IV explains why the distinction is valuable. Finally, Part V considers the implications of a social obligations theory for the question of whether tradable environmental allowances are the property of those who hold them, and argues that the theory does not add anything to the vision of statutory property articulated in Part IV.

\section{WHAT IS STATUTORY PROPERTY?}

The distinction between statutory and private property rests at the core of France-Hudson's argument, but only a limited definition is offered. "One response" to the creation of property-like rights in environmental management legislation is "to put a gloss on these rights by classifying them as a new category of property such as 'statutory property' subject solely to the provisions of the relevant legislation". ${ }^{7}$ It is said that statutory property is property that is "solely governed by the rules contained in the statute that created it and not subject to the general rules and statutes dealing with real or personal property". ${ }^{8}$ This gloss is said to delegitimise statutory property by implying that it is "somehow not 'proper' property" and that this is "likely to lead to uncertainty and increased costs" and "unintended consequences". ${ }^{9}$ France-Hudson argues that there are uncertainties and ambiguities "attendant on statutory property" that affect the security, attractiveness and value of those rights and the success of the regulatory regimes in which they are created. ${ }^{10}$

France-Hudson's framing of statutory property appears to derive from Grinlinton's argument that the Resource Management Act creates a new form of statutory property, governed only by the legislation that creates the rights rather than the traditional principles of property law. ${ }^{11}$ Grinlinton's argument is made in the specific context of the Resource Management Act, ${ }^{12}$ which expressly provides that a "resource consent is neither real nor personal property", ${ }^{13}$ the implication being that a resource consent is either not property at all, or some other type of property. ${ }^{14}$ It is not clear that the

7 France-Hudson, above n 1, at 411-412.

8 At 423

$9 \quad$ At 412.

10 At 412

11 Grinlinton, above n 6, at 296.

12 At 296: "one way to characterize resource consents under the RMA is as a new form of 'statutory property' analogous to a bare license coupled with the right to use and/or take whatever natural resources are allowed in terms of the consent".

13 Resource Management Act, s 122(1).

14 Grinlinton, above n 6, at 293. 
term was intended to apply to rights under different regimes like the ETS or the QMS. A provision such as s 122(1) of the Resource Management Act is unusual (although not without precedent), ${ }^{15}$ and the issue of property defined to be "not property" does not arise frequently.

Concepts of "statutory", "regulatory" or "hybrid" property are frequently discussed in the context of tradable environmental allowance regimes. ${ }^{16}$ As will be shown, the point of distinction is not that this property is solely governed by the statute to which it owes its creation. Rather, statutory property is distinct from private property because: (a) its nature and bounds are defined by the statute that creates it (rather than the common law); and (b) it exists only to fulfil a specific role within a regulatory regime, giving it a "public" rather than a "private" character. The regulatory regime may constrain how statutory property is governed, but that is not a necessary feature. ${ }^{17}$

There is value in distinguishing statutory property from private property because it recognises the differences in the rights created. The idea that regulation can create property is not a new one. ${ }^{18}$ Just as property is a form of regulation, "regulation is a form of property" that can create endowments for those subject to a regulatory regime. ${ }^{19}$ Because these rights are born of a regulatory regime, rather than the sedimentary layers of the common law, "[t]hey do not have all of the characteristics of traditional property rights." 20

15 The legislation establishing the sulfur dioxide allowance program in the United States provides that allowances "[do] not constitute a property right": 42 US Code $\S 7651 \mathrm{~b}(\mathrm{f})$. The express deeming of allowances to not constitute property is a longstanding feature of United States clean air legislation. Two rationales drive the provision. The first is to respond to environmentalists' concerns about creating a "right" to pollute. The second is to create regulatory flexibility by insulating the regime from the takings provisions in the United States Constitution. See Daniel H Cole "Clearing the Air: Four Propositions about Property Rights and Environmental Protection" (1999) 10 Duke Envtl L \& Poly F 103 at 113.

16 A variety of terms are used to describe the same concept in the literature. I will use "statutory" property as it is France-Hudson's preferred term.

17 As Fogarty J observed in respect of the Resource Management Act: "To the extent that it does in fact allow property rights under the RMA, the common law as to real and personal property will apply, subject to constraints in the specific provisions of the statute." Armstrong v Public Trust [2007] 2 NZLR 859 (HC) at [23].

18 Charles A Reich "The New Property" (1964) 73 Yale LJ 733. Reich describes how the modern state created economically valuable interests of significance to the holders of those interests, but that lay outside traditional definitions of property. Property-like characteristics were derived from the substantive and procedural rights that protected those interests.

19 Richard B Stewart "Privprop, Regprop, and Beyond" (1989) 13 Harv J L \& Pub Poly 91 at 92.

20 At 92. 
How can statutory property differ from private property? ${ }^{21}$ There are many possibilities. Limitations or prohibitions on the transferability of regulatory rights are often built into the regulatory framework that creates the rights, ${ }^{22}$ in contrast to private property, which is generally freely alienable. Regulatory rights may be of limited duration, or subject to levels of permissible state interference that do not resemble traditional private property. ${ }^{23}$ Moreover, statutory property is fundamentally distinguishable from private property because it is created for a reason, meaning it is instrumentally connected to a distinct social objective. ${ }^{24}$

Property rights created through regulatory regimes exist precisely because private property rights were historically ineffective at governing open access resources, given the limitations of nuisance and other private law actions in tort. ${ }^{25}$ Tradable environmental allowances have the appearance of property rights, but their regulatory origins mean that, unlike private property, those rights "can be alloted as society thinks best". ${ }^{26}$ The connection between property-like rights created by statute and democracy has been a key justification for the development of tradeable environmental allowance regimes, ${ }^{27}$ and distinguishes the rights created from rights governed solely by private law. Unlike private property, statutory property is shaped by political pressures associated with restricting the use of an open access resource that was previously freely accessible. ${ }^{28}$

Statutory property also depends more strongly upon state enforcement for its existence than traditional forms of private property. I can maintain my valuable interest in land by warding off an

21 I say "can ... differ" because statutory property need not substantively differ from private property (other than the source of the endowments created), though it often will.

22 Stewart, above n 19, at 94 .

23 At 94-95. See also Bonnie G Colby "Cap-and-Trade Policy Challenges: A Tale of Three Markets" (2000) 76 Land Economics 638 at 648-650.

24 See for example Sabina Manea The Instrumentalization of Property: Legal Interests in the EU Emissions Trading System (Kluwer Law International, Alphen aan den Rijn, 2014) at 156-159. Like France-Hudson, Manea's analysis begins with Armstrong DLW GmbH v Winnington Networks Ltd [2012] EWHC 10, [2013] Ch 156, but she ultimately draws a different conclusion: emissions entitlements are property, but are subject to crucial limitations as a result of being situated within a regulatory framework. Manea prefers the term "instrumental property".

25 James E Krier "Marketable Pollution Allowances" (1994) 25 U Tol L Rev 449 at 451.

26 At 453

27 See for example Bruce A Ackerman and Richard B Stewart "Reforming environmental law: the democratic case for market incentives" (1988) 13 Colum J Envtl L 171.

28 Rose, above n 2, at 242; and David AC Bullock "Political Costs and the Challenge of Tradable Environmental Markets" Geo Envtl L Rev (forthcoming). 
intruder who attempts to make an incursion across my boundary. ${ }^{29}$ My emissions units, however, are only valuable because the state defines what they are, can monitor who else is emitting and is able to enforce the regulatory regime. As Rose observes: "Hybrid property rights in environmental law can only exist where our governmental institutions have the capacity to run the regimes". ${ }^{30}$ Property created by statute: ${ }^{31}$

... has no meaning at all other than that generated by its parent legislative framework. Being derived comprehensively and exhaustively from that legislation, statutory property has only the ambit conferred by the statute itself.

This gives property created by statute inherently public qualities, owing as it does "its existence and management to regulation". 32

What this discussion shows is that the description of statutory property as property "subject solely to the provisions of the relevant legislation" does not well encapsulate the usual distinction between statutory and private property, even if it does explain the peculiarities created by s 122(1) of the Resource Management Act. ${ }^{33}$ The better view is that statutory property is property created and defined by statute, and private property is property created and defined by the common law. As Rose describes it, statutory property rights "combine Leviathan with private property". ${ }^{34}$ The source of duties associated with property created by statute and "traditional" property are necessarily different. ${ }^{35}$ However, there is no inherent reason why statutory property would not be governed by the same rules as private property unless there is something in the statutory regime that necessarily excludes ordinary common principles.

France-Hudson's framing of the question contains an assumption that statutory property is somehow lesser than private property in terms of its legitimacy, security, value and systematic

29 This is recognised in New Zealand law. Section 56(1) of the Crimes Act 1961, for example, provides a defence to those who use force in defence of land or a building in which they have peaceable possession.

30 Carol M Rose "The Several Futures of Property: Of Cyberspace and Folk Tales, Emission Trades and Ecosystems" (1998) 83 Minn L Rev 129 at 167. See also Clive L Splash "The Brave New World of Carbon Trading" (2010) 15 New Pol Econ 169 at 180.

31 Kevin Gray "Regulatory Property and the Jurisprudence of Quasi-Public Trust" (2010) 32 Syd LR 221 at 224.

32 Rose, above n 30, at 164.

33 France-Hudson, above n 1, at 411-412.

34 Rose, above n 2, at 236.

35 Simon Douglas and Ben McFarlane "Defining Property Rights" in James Penner and Henry E Smith (eds) Philosophical Foundations of Property Law (Oxford University Press, Oxford, 2013) 219 at 240. The authors observe that, if one accepts the "exclusion" thesis of private property, property arises in physical things simply from the duty not to physically interfere with that thing. For non-physical things the content of the duties must be specified, typically by legislation. 
efficacy. ${ }^{36}$ As Grinlinton uses the term, "statutory property" is lesser than private property because the statute that creates it defines it to be something other than private property. As the term is used more generally in the literature it is not the case that statutory property is necessary lesser than private property. ${ }^{37}$ The real point is that statutory property is different to private property in its origins, and this can mean such rights are also different in substance. In many cases it is not clear that the distinction matters much. For example, France-Hudson claims that Armstrong $D L W$ GmbH $v$ Winnington Networks $L t d,{ }^{38}$ a case concerning the consequences of a purchase of stolen emissions units, demonstrates "the sorts of issues that can arise in this context". ${ }^{39}$ But the categorisation of property as "statutory" or "private" has no significance when assessing whether a theft has occurred. ${ }^{40}$ The question in Armstrong was not whether emissions units were private property or statutory property - it was whether they were property at all (and, if so, what remedies were available).

\section{TWO PROPERTY QUESTIONS}

It is possible to identify two distinct property questions relevant to tradeable environmental allowances. ${ }^{41}$ The first is whether the holder of an allowance has property in the allowance or licence itself. This first question was the question facing the Court in Armstrong: are an allowance holder's rights in an allowance good against the world if someone takes an allowance from the holder without permission? The second question is whether the rights attached to an environmental allowance are property rights in a particular resource. For instance, this question asks whether a right to pollute or catch fish derived from holding an allowance is in the nature of a property right, or some different form of interest. An allowance can both "embody a right and evidence a right". ${ }^{42}$ The distinction can

36 France-Hudson, above n 1, at 412 and 415.

37 Statutory property may be less valuable or secure than private property, depending on the provisions of the statute creating it. Ultimately any comparison of the value, security or efficacy of statutory and private property rights must be answered empirically.

38 Armstrong, above n 24.

39 France-Hudson, above n 1, at 412.

40 Theft is the unlawful taking of property. It does not matter whether that property is categorised as "private", "statutory" or anything else, so long as it is property. In New Zealand, for example, s 219(1)(a) of the Crimes Act defines theft as the act of "dishonestly and without claim of right, taking any property with intent to deprive any owner permanently of that property or of any interest in that property".

41 Cole, above n 15, at 113-114. Cole observes that the provision in United States clean air legislation, 42 US Code $\S 7651 \mathrm{~b}(\mathrm{f})$, that provides that emissions allowances "[do] not constitute a property right" "is premised on the confusion between property rights in something and the thing itself. It provides that an emissions allowance is not 'a property right' but expressly recognizes property rights in emission allowances. According to the section's express terms, utilities can receive, hold (i.e., process), and transfer (i.e., alienate) allowances. ... These are certainly valuable property rights in emission allowances." (Footnotes omitted).

42 Arianna Pretto-Sakmann Boundaries of Personal Property: shares and sub-shares (Hart Publishing, Oxford, 2005) at 74 (discussing shares). 
be illustrated with an example from a different context: a person may have property in a bill of lading (that is, they own the piece of paper), but the bill of lading also embodies a right of the possessor to take possession of a consignment of goods.

France-Hudson blurs these two questions. His discussion of exclusivity, for instance, compares rights under the ETS and the QMS. On the ETS, it is argued that the Climate Change Response Act 2002 confers "an exclusive right to deal with the units held in the holder's account". ${ }^{43}$ This argument addresses the question of whether allowance holders have property in their allowances (that is, in the thing that evidences a right). On fisheries, the author states that individual transferable quota is "exclusive in the sense that a quota holder's percentage of the catch need not be shared with anybody else" (that is, the right itself). ${ }^{44}$

France-Hudson describes private property as being "absolutely central to the theory underpinning the use of emissions units and quota". ${ }^{45}$ But this argument puts the property cart before the regulatory horse. What is crucial to tradeable environmental allowance regimes is the creation of scarcity in an otherwise open access resource, and the ability of parties holding that scarce access to trade their access rights to others. ${ }^{46}$ The creation of scarcity (through the regulatory exclusion of others) is key to the success of the regulatory regime, and is what gives tradable environmental allowances propertylike characteristics. A regime that expressly states that allowances are private property will nevertheless fail (in a governance sense) if the regulatory regime does not effectively make access to the resource scarce. ${ }^{47}$

Tradeable environmental allowance regimes are often called "property-like" regimes because the effect of creating scarce, tradeable regulatory rights to access resources looks a lot like granting allowance holders a form of property in the resource (the second property question I refer to above). Whether the allowance holder actually owns their allowances - the things evidencing their rights (the first property question, above) - is a separate question from the nature of the embodied rights, and generally less bearing on regime design and the regulatory effectiveness. Issues about ownership of

43 France-Hudson, above n 1, at 418.

44 At 419

45 At 420 .

46 Rose, above n 2, at 235.

47 Even if the Climate Change Response Act 2002 called emissions units "private property" (first question property), the fact the scheme has a "soft cap" on the number of emissions units issued means the scheme is ineffective in making access to the resource, the atmosphere, scarce. It is this lack of scarcity that undermines the ETS (second question property), not the formal description of participants' rights in the units they hold. On the effect of the "soft cap" see Geoffrey Palmer "New Zealand's Defective Law on Climate Change" (2015) 13 NZJPIL 115 at 130. 
allowances are largely only of significance in cases like Armstrong where there is a contest between two claimants in respect of the same allowances. ${ }^{48}$

\section{ANSWERING THE FIRST QUESTION: DO ALLOWANCE HOLDERS OWN THEIR ALLOWANCES?}

Having delineated the two distinct property questions related to the tradable environmental allowances - whether there is property in the allowance, and whether the allowance creates property rights - it is possible to set about answering them. This Part focuses on the first question, namely whether tradable environmental allowances are the property of those who hold them. I approach this question first by examining the common law doctrine set out in Armstrong, before looking at the New Zealand legislation establishing the ETS and QMS. As will be seen, the question can be answered on orthodox principles of property law and statutory interpretation, and does not necessitate recourse to a social obligations theory of property.

\section{A The Common Law Approach: Armstrong}

The Court in Armstrong was concerned with precisely the question raised by France-Hudson, yet the reasoning of the Court on this issue receives little attention. ${ }^{49}$ France-Hudson adopts Low and Lin's assessment of the reasoning in Armstrong as being "unduly convoluted" and long, ${ }^{50}$ and asserts that "[t]his complexity stems from the failure of the relevant legislation to define the legal nature of the emissions allowances in question. ${ }^{51}$ In fact, the Court was able to succinctly address the property question of interest to us here in only 22 paragraphs under the heading "The nature of EUAs as property". 52

48 This property question may also be relevant to whether a person can create a security interest in regulatory property rights of this kind. That question is usually addressed by statute, either by specific provision or by the inclusive definition of "personal property" in s 16 of the Personal Property and Securities Act 1999.

49 France-Hudson, above n 1, at 414: "Eventually, the judge decided that the allowances could not be characterised as a chose in action in a narrow sense (as they could not be claimed or enforced by action), but, to the extent the concept of the chose in action encompasses wider matters of property, they could be described as such. Ultimately, the judge concluded that it did not matter whether an emissions allowance was a chose in action or merely some other form of intangible property".

50 At 415 quoting Kevin FK Low and Jolene Lin "Carbon Credits as EU Like It: Property, Immunity, TragiCO2medy?" (2015) 27 JEL 377 at 377, and observing that the entire judgment was 293 paragraphs and 64 pages long.

51 At 427 .

52 At [40]-[61]. It is fair to say that the more vexing issue for the Court was the remedial question of how such property rights would be vindicated. See for example Duncan Sheehan "Bona Fide Purchase, Knowing Receipt and Proprietary Claims to Land and Carbon Credits" (2013) 24 KLJ 424. 
The Court found there to be ample common law authority to formulate and apply a legal test justifying its conclusion that the emissions units were a form of intangible property. ${ }^{53}$ The question of whether government quotas and licences are intangible property has been the subject of a number of previous decisions, and the Court was content to apply the threefold test set out by Morritt LJ in Re Celtic Extraction. ${ }^{54}$ In short, the Celtic Extraction approach asks: ${ }^{55}$

(1) Is there a statutory framework conferring an entitlement on one who satisfies certain conditions?

(2) Is the exemption or licence transferable?

(3) Does the exemption or licence have value?

It is difficult to take issue with this approach. The test looks for the presence of some of the core features of property at common law: exclusivity (implied by value); a subject (an entitlement); and alienability/transferability (property-like qualities). ${ }^{56}$ Applying the Celtic Extraction test to the ETS and QMS supports characterising emissions units and quota as intangible property. Both regimes create a statutory framework that confers entitlements on those holding emissions units and quota (such as the right to emit greenhouse gases or take certain fish without penalty). Emissions units and quota are both transferable, and valuable markets exist for each.

France-Hudson does not set out this threefold test, yet it appears to provide a ready and doctrinally sound answer able to be imported by a New Zealand court faced with a similar question to that arising in Armstrong, such as the theft of emissions units. It is worth reiterating that the question in Armstrong was not whether emissions units were statutory or private property, it was whether they were property at all. Absent the Court drawing such a distinction, it can be inferred that the Court did not consider emissions units to differ from any other intangible property - a conclusion reached on application of orthodox principles. ${ }^{57}$

53 At [52]-[58].

54 Re Celtic Extraction [2001] Ch 487.

55 The relevant dictum is quoted in full in Armstrong, above n 24, at [56].

56 A common law concept of property can be most fundamentally characterised as a right that relates to a thing that imposes a duty on the rest of the world. See for example Ben McFarlane The Structure of Property Law (Hart Publishing, Oxford, 2008) at 139. Whether a characteristic of property at common law includes alienability can be debated, but inalienability is undoubtedly highly exceptional: see Pretto-Sakmann, above $\mathrm{n} 42$, at $163-165$.

57 Douglas and McFarlane have suggested that where a right does not relate to a physical thing, "it should not be considered as a core case of a property right" at all: Douglas and McFarlane, above n 35, at 238-239. Douglas and McFarlane base this argument (which they acknowledge is not fully explored) on $O B G L t d v$ Allan [2007] UKHL 21, [2008] 1 AC 1, where a majority of the House of Lords refused to extend the tort of conversion to a case of interference with a contractual right. However, $O B G$ Ltd $v$ Allan can be better explained by reference to the narrow confines of the tort of conversion (that is, that it relates only to 


\section{B Statutory Guidance}

Of course, a New Zealand court may choose not to follow Armstrong and to instead strike its own path. A court attempting to answer the question of whether the holder of an emissions unit has property in that unit (the question facing the Court in Armstrong) is likely to begin with the statutory scheme that creates the emissions unit: the Climate Change Response Act. ${ }^{58}$ France-Hudson argues that the statute offers little assistance because it (and the Fisheries Act 1996 in respect of quota) is "silent" as to the legal nature of emissions units. ${ }^{59}$ It is certainly true that the legislation does not explicitly declare emissions units to be the property of those who hold them. This does not mean that the statute has nothing to say on the issue. On the contrary, the legislation provides many indications that emissions units are the property of their holders.

The Act defines "units" to be Kyoto units, New Zealand units and approved overseas units. A New Zealand unit is a unit issued by the Registrar, and Kyoto and approved overseas units are, unsurprisingly, units established under the Kyoto Protocol or overseas registries. ${ }^{60}$ The Act establishes a domestic Registry, and requires the appointment of a Registrar, ${ }^{61}$ for the purpose inter alia of ensuring the "accurate, transparent, and efficient account of ... the issue, holding, transfer, retirement, surrender, and cancellation" of units. ${ }^{62}$

Units are held in various accounts within the Registry. Account holders may apply to the Registrar to transfer units to another account in the Registry (or an overseas registry), and the Registrar must give effect to such transfer applications. ${ }^{63}$ The Minister of Finance has wide discretion to direct the Registrar to transfer units held in Crown accounts. ${ }^{64}$ However, the Minister may not direct the Registrar to transfer units held by an account holder other than the Crown unless one of the limited statutory exceptions applies. ${ }^{65}$ The most significant exception is that the Minister may require units

interference with specific personal property - goods or chattels) rather than a narrow conceptualisation of "property" as a whole: at [100].

58 The same is true for the Fisheries Act 1996, but for the sake of brevity I only examine the Climate Change Response Act here.

59 France-Hudson, above n 1, at 413.

60 Climate Change Response Act, s 4, definition of "unit"; and Kyoto Protocol to the United Nations Framework Convention on Climate Change 2303 UNTS 162 (opened for signature 16 March 1998, entered into force 16 February 2005).

61 Section 11.

62 Section 10.

63 Section $18 C$.

64 Section 7.

65 Section 7(2). 
to be transferred to the Crown in order to comply with New Zealand's obligations under the Kyoto Protocol, so long as reasonable notice (being the opportunity to make written submissions on the transfer) is given to the holder. ${ }^{66}$

If an account holder dies or is wound up their successor becomes the account holder, ${ }^{67}$ able to direct the transfer of units held within the account. The assignee of the property of a bankrupt may be entered on the unit register "as the assignee of the bankrupt's units". ${ }^{68}$ Section $18(1 \mathrm{~A})$ of the Personal Property and Securities Act 1999 provides that a person takes possession of an investment security that is an emissions unit in a variety of ways. For present purposes, the relevant subsection relates to emissions units defined in s 4(1) of the Climate Change Response Act (New Zealand units, Kyoto units and approved overseas units). Section $18(1 \mathrm{~A})(\mathrm{d})$ provides that possession is taken when the unit register established under the Climate Change Response Act records a person as the possessor of the unit. Functionally, this means possession is taken when the unit is transferred into an account in that person's name.

This brief analysis of the Act provides a basis to conclude that an account holder has property in the emissions units held in an account bearing their name. With limited exceptions, that person has the exclusive right to deal with units held in their name, and that right is good against the world. There are some differences between emissions units and other private property, embodied in the legislation. For instance, there are greater possibilities for governmental takings (consistent with the reasons for the ETS' creation), transfers must be approved and actioned by the Registrar, and units exist only within the Registry. For the most part, though, the holders' rights in their units are exclusive, transferable and good against the world (and therefore valuable).

Undoubtedly, a provision in the nature of s 35 of the Companies Act 1993, which states that a share in a company is personal property, would put the legal nature of an emissions unit beyond doubt. But an orthodox analysis of the statutory features of emissions units readily yields the same conclusion. In the absence of a provision like s 122(1) of the Resource Management Act there is no reason to assume that something that looks like property is anything but property.

\section{A Distinction with a Difference?}

The foregoing analysis shows there is no need to distinguish between "statutory property" and "private property" to answer the question facing the Court in Armstrong. Something is either property - a right to a thing good against the world - or it is not. ${ }^{69}$ However, distinguishing between statutory

66 Section 7(2)-(3).

67 Section 18D.

68 Section 18E(3).

69 Henry E Smith "Property as the Law of Things" (2012) 125 Harv L Rev 1691 at 1706. 
property and private property is a useful way to identify the difference between the content of property rights, and may result in constraints on the vindication of those rights. ${ }^{70}$

As noted, France-Hudson adopts Grinlinton's definition of statutory property ("solely governed by the rules contained in the statutes that create them"), which is given in the context of s 122(1) of the Resource Management Act (providing that: "A resource consent is neither real nor personal property"). ${ }^{71}$ There is no equivalent provision in the Climate Change Response Act or the Fisheries Act. Indeed, Grinlinton argues that individual transferable quota is "a hybrid form of property right having elements of a land title and company shares" and that emissions units are a "new form of property right in the nature of a reverse nonexclusive profit a prendre".${ }^{72}$ Grinlinton argues that these rights are property rights; he is not making the case that they are statutory property as he defines it. His definition of "statutory property" does not apply to emissions units or quota because there is no statutory provision deeming emissions units or quota to not be personal property.

It is important to stress the confines of Grinlinton's definition of statutory property because it demonstrates that France-Hudson's response is fashioned to a claim that is not really made. FranceHudson argues that "[r]ather than categorising them [- emissions units and fishing quota - ] as statutory property the simple solution is to recognise that they are actually private property". ${ }^{73}$ But Grinlinton only categorises resource consents as "statutory property" because the Resource Management Act explicitly provides that resource consents are neither real nor personal property. ${ }^{74}$ Where a statute makes no express comment on whether tradable environmental allowances are property, Grinlinton's view - and the view of many scholars ${ }^{75}$ - is that those allowances are property (and not "statutory property", according to Grinlinton's definition).

The express statement in the Resource Management Act that resource consents are not property suggests that Parliament's default understanding is that tradable environmental allowances are private property, unless it provides otherwise. That this is left unsaid in the Fisheries Act and Climate Change Response Act better serves as an indication that Parliament does not doubt that these rights are property, rather than being reflective of a legislative anxiety productive of ambiguity as FranceHudson claims.

Is the distinction between private property and statutory property a worthwhile one in the context of tradable environmental allowances? I think it is. As Grinlinton uses the term in the context of the

70 On the limitations of the tort of conversion at common law, for example, see above $\mathrm{n} 57$.

71 France-Hudson, above n 1, at 423.

72 Grinlinton, above n 6, at 298-300.

73 France-Hudson, above n 1, at 417.

74 Grinlinton, above n 6, at 296.

75 See Part II. 
Resource Management Act it is useful to reflect the statutory categorisation of resource consents as neither real nor personal property. As a theoretical matter, the distinction is useful to describe property defined according to a statutory regime rather than the private law, and to signal the often different content that property created by statute has in comparison to traditional common law property. Practically, the distinction can be significant when considering the rights and duties attached to property created by difference sources, and for courts when considering remedial options to vindicate those rights.

\section{WHAT OF SOCIAL OBLIGATIONS?}

The foregoing sections have shown that a distinction between "private" and "statutory" property is not a particularly problematic one, regardless of the definition of statutory property used. Orthodox property theory can yield the conclusion that tradable environmental allowances are private property, as the Court held in Armstrong. Nevertheless, I want to briefly address France-Hudson's more fundamental argument about the nature of private property, namely that it is an institution embodying norms of social obligation.

France-Hudson's discussion of the social obligations theory comes as a response to two potential problems he sees with treating tradable environmental allowances as private property: private property creates a risk of path-dependence and it raises the possibility that compensation will need to be paid if property is taken. ${ }^{76}$ These problems are a consequence of France-Hudson's case for recognising tradable environmental allowances as private property: the need to give allowance holders greater certainty and security. ${ }^{77}$ Property rights are made secure by limiting the possibility of interference by the state and others, ${ }^{78}$ but this often sits in tension with the regulatory purpose for which they are created.

To solve this tension France-Hudson turns to a "social obligations" theory of the problem. The social obligations theory sits at the core of the fledging "progressive property" school, which seeks to

76 France-Hudson, above n 1, at 422-423. These are not really distinct problems, the path dependency of property rights derives from the protections that require compensation to be paid for takings. In New Zealand these protections are less strong than in jurisdictions like the United States where the ability of the state to take property is limited to takings for "public use" and compensation is required. In New Zealand, Parliament's supreme law making powers enable it to pass legislation taking private property without the payment of compensation. See for example Westco Lagan Ltd v Attorney-General [2001] 1 NZLR 40 (HC); Cooper v Attorney-General [1996] 3 NZLR 480 (HC); and Public Works Act 1981, pt 5.

77 France-Hudson, above n 1, at 424: "the uncertainties attendant on statutory property and the ambiguity of this type of right more generally are likely to have a flow on effect for their security, their attractiveness and value, the extent of engagement with the schemes which rely on them and the success of the schemes overall".

78 See for example James Penner The Idea of Property (Oxford University Press, Oxford, 1997) at 68 and following; and Thomas W Merrill "Property and the Right to Exclude" (1998) 77 Neb L Rev 730. 
challenge the orthodox economic explanations that dominate American property scholarship. ${ }^{79}$ As France-Hudson recognises, Alexander's social obligations thesis argues that property is an institution that serves social as well as individual ends, and therefore embodies norms of social obligations and limitations on the rights of owners directed towards the facilitation of human flourishing.

The theory has been best used to explain property phenomena that cut against economic intuitions, such as recognition of squatters' rights in South Africa ${ }^{80}$ and public beach access easements in New Jersey, ${ }^{81}$ and the unusual exception to trespass recognised in State of New Jersey $v$ Shack. ${ }^{82}$ However, as a general theory of property the social obligations thesis has much less descriptive power, and the school's heavy reliance on a creative use of a small number of outlier cases has been criticised. ${ }^{83}$

Reliance on a "social obligations" theory of property helps France-Hudson to reintroduce the flexibility lost when tradable environmental allowances are recognised as property: "It follows that the social obligation norm of property provides a principled explanation for the fact that owners of property have obligations to the community generally." 84 The content of this "social obligation norm" is unclear, ${ }^{85}$ but we are told that it "demonstrates that the institution of property is flexible enough" to overcome the fears that using private property concepts will create rigidity. ${ }^{86}$ Viewing of property as a broad, flexible, social institution means: 87

79 Gregory S Alexander and others "A Statement of Progressive Property" (2009) 94 Cornell L Rev 743. For a number of the leading works in the progressive property school see Gregory S Alexander "The SocialObligation Norm in American Property Law" (2009) 94 Cornell L Rev 745; Eduardo M Penalver "Land Virtues" (2009) 94 Cornell L Rev 821; Joseph William Singer "Democratic Estates: Property Law in a Free and Democratic Society" (2009) 94 Cornell L Rev 1009; Gregory S Alexander "The Complex Core of Property" (2009) 94 Cornell L Rev 1063; Gregory S Alexander and Eduardo M Peñalver (eds) Property and Community (Oxford University Press, Oxford, 2009); and Jedediah Purdy The Meaning of Property: Freedom, Community, and the Legal Imagination (Yale University Press, New Haven, 2010).

80 Modder East Squatters v Modderklip Boerdery (Pty) Ltd 20048 BCLR 821 (SASC).

81 Matthews v Bay Head Improvement Assoc 471 A 2d 355 (NJ 1984).

82 State of New Jersey $v$ Shack 277 A 2d 369 (NJ 1971).

83 See for example Ezra Rosser "The Ambition and Transformative Potential of Progressive Property" (2013) 101 CLR 107 at 114; Henry E Smith "Mind the Gap: The Indirect Relation Between Ends and Means in American Property Law" (2009) 94 Cornell L Rev 959; and Katrina M Wyman "Should Property Scholars Embrace Virtue Ethics? A Skeptical Comment" (2009) 94 Cornell L Rev 991.

84 France-Hudson, above n 1, at 424.

85 This is a common critique of social obligations theory. While the theory recognises a limitation on the rights of owners "if their property has a sufficient nexus to the need" the theory "does not tell us with much specificity what constitutes such a nexus": Smith, above n 83, at 961.

86 France-Hudson, above n 1, at 424.

87 At 424 . 
... it is not necessary to articulate these rights [- tradable environmental allowances - ] as unique; as a species of "statutory property" limited to the words of the legislation. Instead, we can simply accept that they are private property and be clear about that.

However, France-Hudson has his cake and eats it too: treating environmental allowances as private property makes rights clearer and more secure, but viewing private property as a broad and flexible social institution gives the state the flexibility it needs make its regulatory regime effective.

When it comes to identifying the content of the norm of social obligation incumbent on tradable environmental allowances, France-Hudson looks to the provisions of the legislation that create the property. The recourse is surprising because France-Hudson makes the effort to stress that we are dealing with private property not statutory property. France-Hudson argues that emissions units meet statutory liabilities rather than creating rights in a resource, meaning they are property but do not create property, so the government can change "regulations surrounding emitting activities" without taking property. ${ }^{88} \mathrm{He}$ further argues that because individual transferable quota gives a right to catch fish, rather than a right in fish themselves, it too "insulates the Crown from claims for compensation". ${ }^{89}$ Indeed, France-Hudson goes so far as to commend "the architects of these rights" for having done "a good job of balancing the tension between utility of private property in this area and some of the associated concerns". 90

Sourcing the relevant social obligations from statute is confusing in the context of FranceHudson's argument. It suggests that these crucial social obligations are not embedded within the framework of private property itself. Rather, those social obligations appear to only exist because Parliament has legislated them into a particular form of property (property which it also created through legislation). What was remarkable about a case like State of New Jersey $v$ Shack was that the Court found the landowner's rights to be subject to social obligations in the absence of any legislation, suggesting those obligations were embedded in the law of property itself. If legislation had existed allowing the lawyers to enter the farm without the consent of the owner, not only would the result in the case have been uncontroversial, it would have shed little light on the fundamental nature of private property.

It may well be, as France-Hudson argues, that the restrictions on property rights created by the emissions trading and fisheries legislation in New Zealand are reflective of embedded social obligations. ${ }^{91}$ But those social obligations derive from the legislative framework that creates the

88 At 425 .

89 At 426

90 At 426 .

91 See also Ben France-Hudson "Surprisingly Social: Private Property and Environmental Management" (2017) 29 JEL 101. 
property, rather than anything inherent in the nature of private property itself. For that reason, the New Zealand emissions trading and fisheries examples do little to support a broader social obligations theory of private property. On the contrary, those regimes are examples that show that when property is created by statute, and limitations or extensions on those rights are included in that constituent statute relative to the general common law of property, the statutory qualifiers prevail. If the social obligations incumbent upon owners of tradable environmental allowances derive from statutory obligations, rather than obligations located in private law, France-Hudson's thesis begins to look a lot like the preferred definition of statutory property advanced in this article.

\section{THE VALUE OF STATUTORY PROPERTY}

The definition of statutory property used in this article - property rights that are created and defined by statute - provides a useful means of distinguishing common law property from the potentially more limited contours of property created by statute. This has both theoretical value, and practical usefulness, because it indicates that difference in content may derive from the source of the property right. Statutory contours may involve limitations reflective of social obligations - statutory property is usually created to serve a particular public purpose as part of a regulatory regime. ${ }^{92}$ However, because the source of these social features is a statutory regime, the examples of emissions units and fishing quota shed little light on the nature of "private" (or common law) property. Those social obligations reflect explicit legislative choices, not the "inherent responsibilities" of private property. ${ }^{93}$ In fact, the need to attach social obligations (or limitations) to property through express legislative provision suggests that the ordinary features of private property are generally inapt to serve the social functions of regulatory regimes like the ETS and QMS without statutory intervention and modification.

A social obligations theory of private property provides a circuitous route to explain tradeable environmental allowances. The alternative is to view tradable environmental allowances as property that is created and defined by statute, but is governed by the private law of property (it is property, after all) to the extent that the constituent statute does not contradict the common law. That is, to view tradable environmental allowances as statutory property.

92 Manea, above $\mathrm{n} 24$.

93 Contrast France-Hudson, above n 91, at 127 concluding that New Zealand's tradeable environmental allowance regimes support a social obligation theory of private property, and that our idea of private property need not be reinvented because "[w]e already have a property regime with inherent responsibilities". 
